Vol. 07, No. 02, pp. 1-15, June 2014

\title{
EXPERIMENTAL STUDY OF ZINC POWDER PREPARATION BY ELECTROCHEMICAL METHOD
}

\author{
Muwafaq Mahdi Abd Al Shammari \\ Assistant Lecturer, College of Engineering, Diyala University, Iraq \\ E-mail: muwafaq68@gmail.com \\ (Received: 27/1/2013; Accepted:25 /4/2013)
}

\begin{abstract}
This research has been done to study and diagnose operational factors and conditions affecting the zinc powder specification and efficient performance of the electrochemical process . The selection of the optimal conditions for the powder preparation at an average particle size up to $100 \mu \mathrm{m}$ will be investigated with high productivity and efficiency.

The results indicated that the adoption of electrochemical technique was suitable for obtaining zinc powder at average particle size less than of $100 \mu \mathrm{m}$ directly by $77.8 \%$ of the total amount prepared, purity of $99.2 \%$ and current efficiency (64.9\%). The optimal conditions were through using an electrode cathode of stainless steel, zinc as an anode in alkaline medium of sodium hydroxide $(200 \mathrm{~g} / \mathrm{l})$, zinc ions concentration up to $(6 \mathrm{~g} / \mathrm{l})$, current density $0.19 \mathrm{amp} / \mathrm{cm}^{2}$ on the cathode electrode, and electrochemical deposition time of (2 hrs.). Also empirical relations obtained by correlating the effective parameters using nonlinear regression with correlation coefficients (0.97 and 0.92) and the relation s are:

Current efficiency $(Y 1)=-884.65-2.5 X_{1}-1351.2 X_{1} X_{2}+55.62 X_{1} X_{3}-0.04 X_{1}^{2}+12945.18$ $\mathrm{X}_{2}-1715.78 \mathrm{X}_{2} \mathrm{X}_{3}+878.99 \mathrm{X}_{2}^{2}-0.96 \mathrm{X}_{3}-0.39 \mathrm{X}_{3}^{2}, \mathrm{R}=0.97$

Productivity $\left(\mathrm{Y}_{2}\right)=6225.1+174.3 \mathrm{X}_{1}+3442.8 \mathrm{X}_{1} \mathrm{X}_{2}-196.6 \mathrm{X}_{1} \mathrm{X}_{3}-58189.7 \mathrm{X}_{2}+12689.7$ $\mathrm{X}_{2} \mathrm{X}_{3}-1704.0 \mathrm{X}_{2}^{2}-1224.7 \mathrm{X}_{3}-2.4 \mathrm{X}_{3}^{2}, \mathrm{R}=0.92$
\end{abstract}

Keywords: zinc powder, electrodeposition, current efficiency, powder productivity.

\section{1- INTRODUCTION}

In recent years, powder metallurgy has grown rapidly, both in the number of metal powders produced and in the quantity produced. Over the last ten years, double increasing noticed in the production of uncommon metal powders. Powder metallurgy covers a broad spectrum of manufacturing processes. Both the mechanical methods and the chemical/electrochemical methods for producing various metal powders are used in the 
manufacturing process such as atomization, reduction, electrodeposition, etc. ${ }^{[1]}$. Powder Metallurgy (PM) has an impressive development including different metals, metal oxides as $\mathrm{Al}, \mathrm{Fe}, \mathrm{Zn}, \mathrm{Ni}, \mathrm{Cu}, \mathrm{ZnO}, \mathrm{CuO}$, etc., and coating the powder particles with a metallic layer to improve the properties of basic materials ${ }^{[2,3,4,5,6,7]}$.

The electrochemical preparation of zinc powder is one of the best methods adopted industrially and competes other methods in terms of cost, economic feasibility, and high purity powders ${ }^{[8]}$. It is well known that zinc electrodeposits as metals have special relevance due to their anticorrosive properties by the formation of passive layers contacted with air, and in aqueous solution. ${ }^{[9]}$. At present, approximately $60 \%$ of the zinc consumed worldwide originates from mined ores and $40 \%$ from recycled or secondary zinc. The level of recycling is increasing each year, in step with progress in the technology of zinc production and zinc recycling ${ }^{[10]}$. Zinc has been an attractive material as an anode for secondary alkaline batteries which are widely used in aerospace, military commercial and various other fields of surfactants, a single composition of the main electrolyte constituents is usually selected in research papers ${ }^{[11]}$. Ballesteros ${ }^{[12]}$ studied the influence of polyethylene glycol on the zinc electrodeposition and nucleation, they showed that the zinc obtained in presence of polyethylene glycol at $-1.6 \mathrm{~V}, \mathrm{SCE}$ are smoother. While Recendiz ${ }^{[13]}$ et al. they investigated mass transport in the rotating cylinder electrode (RCE) for the $\mathrm{Zn}(\mathrm{II})$ recovery from dilute solutions. The $\mathrm{Zn}(\mathrm{II})$ concentration was 0.019 mole $\mathrm{dm}-^{3} \mathrm{ZnSO}_{4} \cdot 7 \mathrm{H}_{2} \mathrm{O}(1270 \mathrm{ppm} \mathrm{Zn(II))}$ in 0.037 mole $\mathrm{dm}^{-}{ }^{3} \mathrm{Na}_{2} \mathrm{SO}_{4}$ at $\mathrm{pH}=2$. Based on the analysis of $\boldsymbol{S} \boldsymbol{h}=\boldsymbol{a} \boldsymbol{R} \boldsymbol{e}^{\boldsymbol{b}} \boldsymbol{S} \boldsymbol{c}^{\mathbf{0 . 3 5 6}}$ correlation, the value of the ( constant a), associated with shape and cell dimensions, was 0.65 ; while the (value of b), associated with the hydrodynamic regime, was $\left(0.48^{)}\right.$. Zhu and Zhang ${ }^{[14,15]}$ found a new method for modification of zinc powder according to their results, the ultrasonic impregnation technique, can be used to handle the zinc powder for improving the electrochemical performance of the corresponding zinc electrode. Vazquez-Arenas et al. ${ }^{[16]}$ evaluated the thermodynamic diagrams, X-ray diffraction and electrochemical analysis and the solution chemistry of the $\mathrm{Zn}(\mathrm{II})-\mathrm{NH}_{4} \mathrm{Cl}-\mathrm{NH}_{3}-\mathrm{H}_{2} \mathrm{O}$ system as well as the feasibility of zinc electro recovery at different $\mathrm{pH}$ values. The use of higher $\mathrm{pH}$ values is restricted due to formation of $\mathrm{ZnO}(\mathrm{s})$ and the increase of ammonia evaporation at $\mathrm{pH}>10$. Therefore, experimental conditions around neutral $\mathrm{pH}(5.5<\mathrm{pH}<8)$ are potentially suitable to perform the zinc electrodeposition.

The reactions of cathode electrode are occur in electrochemical cell of zinc powder preparation as follow:

$$
\begin{array}{lll}
\mathrm{Zn}^{+2}(\mathrm{aq})+2 \mathrm{e} \longrightarrow \mathrm{Zn}(\mathrm{s}) & \mathrm{E}^{\mathrm{o}}=-1.216 \quad \mathrm{~V} \\
2 \mathrm{H}_{2} \mathrm{O}(\mathrm{l})+2 \mathrm{e} \longrightarrow \mathrm{H}_{2}+2 \mathrm{OH}^{-} \quad \mathrm{E}=-0.828 \mathrm{~V}
\end{array}
$$


The above $\mathrm{E}^{\mathrm{o}}$ values are relevant to the release of hydrogen from a clean platinum electrode surface, whereas it is released from the surface of other metals at much higher potentials. Understanding the hydrogen release and overpotential phenomena is of great importance in the zinc deposition process. The hydrogen gas released at the cathode also affects the morphology of the powder. In the case of industrial applications, larger electrodes are used and the gas release is more evident and important. In the first stages of deposition, when the reaction area of zinc deposition is small, the release of hydrogen bubbles will cause parasites or dendrites and potential oscillation in the cell ${ }^{[11]}$.

\section{2- EXPERIMENTAL WORK}

Five main parameters were chosen to be investigated in this research; electrolyte nature (acidic or alkaline), current density (C.D.), zinc ion concentration, time of electrolysis and effect of mixing (natural or mechanical mixing). Other parameters such as temperature and distance between electrodes were kept constant. The preparation of metal powder by electrochemical process may be follows different techniques, for example; preparation in presence of concentrated alkaline medium of sodium hydroxide or very diluted acidic medium but not concentrated acidic electrolyte, since the vagarious reaction between the metal ion and the acid lead to loss in both the productivity and current efficiency.

Therefor; Zinc sulfate was dissolved in distilled water, then the solutions analyzed to obtain the desired concentration of zinc ions $(12 \mathrm{~g} / \mathrm{l})$ to proceed two experiments at constant current density $\left(0.12 \mathrm{amp} / \mathrm{cm}^{2}\right)$ with two different medium (the first is alkaline of $200 \mathrm{~g} / \mathrm{l}$ sodium hydroxide and the second diluted acidic solution of sulfuric acid with $\mathrm{pH}=6$ ).

Then the prepared solutions were used in the electrolysis bath (electrochemical cell as shown in fig. (1)) of dimensions $(120 \times 155 \times 100) \mathrm{mm}$. with Stainless steel plate as the cathode electrode and $\mathrm{Zn}$ plates were used as anode electrode. Both plates were with same dimensions $(100 \times 120 \times 2) \mathrm{mm}$. They were set in parallel and immersed vertically in the bath with time of electrolysis ( $3 \mathrm{hrs}$.). The produced powder passed $100 \mu \mathrm{m}$ sieves to analyze the particle size distribution. The productivity in alkaline medium was twice of acidic, while the current efficiency in alkaline medium was three times of the acidic medium. Therefore the alkaline medium was chooses to proceed the other experiments.

The initial concentrations of zinc ions $(3,6,12,18$ and $24 \mathrm{~g} / \mathrm{l})$ are used in this work to prepare zinc powder under the constant temperature ranging from $35^{\circ} \mathrm{C}$ to $40^{\circ} \mathrm{C}$. Current densities of $0.06,0.09,0.12,0.15$ and $0.19 \mathrm{Amp} / \mathrm{cm}^{2}$ were tested. The effect of the operating time on the particle size was tested in a 1,2,3,4 and 6 hours.

The cathode powder produced washed with acidified distilled water $(\mathrm{pH}=4)$ several times to remove the traces of alkali deposits from the powder. Then, the powder was dried in 
inert atmosphere or under vacuum for $2 \mathrm{hrs}$. at $80{ }^{\circ} \mathrm{C}$ and all powder samples were passed through $100 \mu \mathrm{m}$ sieve. Different weight of Zn powder was obtained in each experiment; therefore the electrolysis current efficiency was calculated by equations (1) and (2).

$\mathrm{wt}_{\mathrm{d}}=\mathrm{A}_{\mathrm{wt}} \mathrm{It} / \mathrm{n} \mathrm{F}$

Current Efficiency $(\%)=\left(w_{d} / w_{t}\right) \times 100$

Where:

$\mathrm{wt}_{\mathrm{t}}$ : total weight (gram) of powder produced in time of experiment

$\mathrm{wt}_{\mathrm{d}}$ : the desired weight $(\mathrm{gram})$ of zinc powder $(<100 \mu \mathrm{m})$

$\mathrm{A}_{\mathrm{wt}}$ : atomic weight of $\mathrm{Zn}(65.37 \mathrm{~g} / \mathrm{mole})$

I : current in ampere

$\mathrm{t}$ : time in second

$\mathrm{n}:$ zinc valence which is 2

and F : Faraday constant (96484 coulombs per mole.)

\section{3- RESULTS AND DISCUSSION}

The using the of sodium hydroxide with concentration of $(200 \mathrm{~g} / \mathrm{l})$; as we have pointed out in the above; the alkaline medium is much better than the acid medium since of the obtained productivity which twice those aggregated from the acid medium, as well as apply to the efficiency of the current as shown in table (1). This leads to low lost in electricity power and this was adopted alkaline medium in the preparation of zinc powder.

\section{1 - Effect of zinc ions concentration}

Based on the principles of preparation of metal powders by electrochemical process low concentrations of metal ions were used to obtain fine particle size and vice versa. On this principle a set of experiments are proceed, by changing the initial zinc ion concentration from (3 - 24) gm. / 1 and constant current density (0.12 Amp. $\left./ \mathrm{cm}^{2}\right)$ on stainless steel cathode. The results as shown in Figs ( 1 and 2) pointed that if the increasing of zinc ions concentration more than $12 \mathrm{~g} / \mathrm{l}$ the current efficiency will increase exponentially, while the productivity of powder with particle size less than $100 \mu \mathrm{m}$ will decreased rapidly.

From other hand if the zinc ions concentration decreased less than $6 \mathrm{~g} / \mathrm{l}$ the current efficiency will dropped to $60 \%$ or less, and the productivity will decreased also, this will led to loss in current and power. Therefore the best limits of zinc ions concentration lie between 6-12 g/l for aggregate highest productivity of zinc powder of desired particle size (less than $100 \mu \mathrm{m})$ and with optimum current efficiency.

Although the productivity at concentration $6 \mathrm{~g} / \mathrm{l}$ was higher than the productivity at concentration $12 \mathrm{~g} / \mathrm{l}$ by more than $12 \%$, the current efficiency dropped about $5 \%$. Therefore, 
the concentration of $6 \mathrm{~g} / 1$ chooses as the best concentration to obtain highest productivity with best current efficiency.

\section{2 - Effect of current density}

A set of experiments proceeded to understand the effect of current density on particle size distribution of zinc powder with a range of (0.06 to 0.19) amp. $/ \mathrm{cm}^{2}$. Electrodes of stainless steel was used as cathode and zinc as anode with electrolyte contain $6 \mathrm{~g} / \mathrm{l}$ of zinc ions concentration, and operating time $3 \mathrm{hrs}$.

The curves in figures (3 and 4) show the relation of current density with current efficiency and productivity respectively. The results show when the current density increased leads to obtain finer particles size, but this accompanied by a decline in current efficiency. From figures, when the productivity $0.13 \mathrm{gm} . /\left(\mathrm{cm}^{2} . \mathrm{hr}\right.$.) the current efficiency was $66 \%$ in case of current density ( $\left.0.19 \mathrm{amp} . / \mathrm{cm}^{2}\right)$ but if the current density $\left(0.06 \mathrm{amp} . / \mathrm{cm}^{2}\right)$ the values of productivity and current efficiency are $0.037 \mathrm{gm} . /\left(\mathrm{cm}^{2} . \mathrm{hr}\right.$.) and $77.8 \%$ respectively.

Powder prepared with current density higher than $\left(0.19 \mathrm{amp} . / \mathrm{cm}^{2}\right)$ is not desired for the following reasons:

a- Current efficiency will dropped less than $66 \%$ and lead to loss in power

b- An increase in current density will gives significantly increase in hydrogen gas evolution, this leads to the falling of the powder deposited on cathode causing reaction it with component of electrolyte and finally increasing of zinc ions in it.

c- Jumped in temperature of electrolyte higher than $50{ }^{\circ} \mathrm{C}$ so should require providing the cell with a cooling coil to maintain the temperature and that mean more cost.

So that the adoption of the current density $\left(0.19 \mathrm{amp} . / \mathrm{cm}^{2}\right)$ is suitable to get a higher zinc powder productivity with acceptably current efficiency.

\section{3 - Operating time of electrolysis}

The time of electrodeposition is one of the important factors in the preparation of metal powders by the electrochemical process. As is well known that the surface area of the reaction or deposition on the cathode increases with time as a result of the deposition process and this leads to a decline in current density and thus obtain the powder with large granularity over time. Therefore a number of experiments to determine the optimal electrodeposition time for zinc powder with highest productivity possible and the highest efficiency of current.

The results obtained indicate that the current efficiency of the operating at the starting is $54 \%$ then getting dramatic increase with the increase of time up to $76 \%$ as shown in figure (5). 
While, the maximum productivity obtained after two hours of operating time $(0.112 \mathrm{gm} /$ $\left.\left(\mathrm{cm}^{2} . \mathrm{hr}.\right)\right)$ then the decline start as shown in Figure (6), due to the liberating of hydrogen gas intensely at the starting causes of low current efficiency. Liberating of hydrogen gas decrease gradually as a result of the increased surface area which led to decrease in current density and that will be reflected on improvement in current efficiency. These changes in the operation condition of process are led to a loss in zinc powder deposited on the cathode. A large deposited will falling to the cell bath and react with component of electrolyte that means loss in product. Therefore $2 \mathrm{hr}$. as time of electrolysis is optimum operating time to obtain zinc powder with good productivity and current efficiency.

\section{4- Effect of mixing}

The mixing leads to increase the rate of mass transfer then increase in the efficiency of the current. While in the preparation of metal powders, the nature of the particle size distribution depends on the ratio of free hydrogen gas evolution(secondary reaction) compared with depositing metal (main reaction) and the higher ratio led to get the small particle size and vice versa.

To illustrate the effect of mixing two experiments carried out; the first without the presence of mechanical mixing (dependence on liberate hydrogen gas) and the second in presence of mechanical mixing with speed of rotating $300 \mathrm{rpm}$ as shown in table (2). The results have been obtained stating that the current efficiency improved in presence of mechanical mixing to reaching $84 \%$.Compared without mixing was $66 \%$. But the productivity of powder with particle size distribution less than 100 microns dropped significantly, reaching $29 \%$ in presence of mixing, and $92 \%$ in the absence of it. This means that the ratio of powder rejected very high causing the loss in production. Therefore, not favor mechanical mixing in the case to get the small particle size or use of mixing at a very low rate. The final analytical results refer to obtaining zinc powder with high purity $99.2 \%$ and with ratio $77.8 \%$ of the total amount prepared.

\section{5- The Empirical Correlations}

The experimental results obtained are correlated by a mathematical relationship. Second order polynomial model was used to represent these variables and the following empirical correlation obtained:

$$
\begin{aligned}
& Y_{1}=a_{0}+a_{1} X_{1}+a_{2} X_{1} X_{2}+a_{3} X 1 X_{3}+a_{4} X_{1}^{2}+a_{5} X_{2}+a_{6} X_{2} X_{3}+a_{7} X_{2}^{2}+a_{8} X_{3}+a_{9} X_{3}^{2} \ldots \ldots \\
& Y_{2}=a_{0}+a_{1} X_{1}+a_{2} X_{1} X_{2}+a_{3} X 1 X_{3}+a_{4} X_{1}^{2}+a_{5} X_{2}+a_{6} X_{2} X_{3}+a_{7} X_{2}^{2}+a_{8} X_{3}+a_{9} X_{3}^{2} \ldots
\end{aligned}
$$


Where $\mathrm{Y}_{1}$ and $\mathrm{Y}_{2}$ are current efficiency $(\%)$ and productivity $\left(\mathrm{gm} . / \mathrm{cm}^{2} . \mathrm{hr}\right)$ respectively; X1 the zinc ions concentration (gm. /l); $\mathrm{X}_{2}$ current density (ampere/cm²); $\mathrm{X}_{3}$ the time of electrolysis (hr.); and $\mathrm{a}_{0}, \mathrm{a}_{1}, \mathrm{a}_{2}$ a9 are constants.

The constants of equations (3) and (4) were evaluated by using nonlinear estimation regression (STATISTICA 7 software). The non-linear regression for Current efficiency ( $\left.\mathrm{Y}_{1}\right)$ with Correlation coefficient, $R=0.97$ and Productivity $\left(Y_{2}\right)$ with Correlation coefficient, $R=$ 0.92 yield the constants $\mathrm{a}_{0}, \mathrm{a} 1, \mathrm{a} 2 \ldots . \mathrm{a} 9$ of equations (3) and (4) given in table (1).

The two mathematical models of current efficiency and productivity are given a good fitting between the experimental (observed) and the predicted (calculated by model) values as shown in fig. (7 and 8) and that mean the high correlate of the variables of the process.

\section{4- CONCLUSIONS}

The present paper was devoted to the direct precipitation of zinc powder by electrochemical process to obtain particle size less than 100 microns using a bath of sodium hydroxide with concentration $200 \mathrm{~g} / \mathrm{l}$. Generally, it was not recommend using the neutral and acidic solutions due to the decrease of productivity and the decline in the efficiency of the current. Also it is not prefer to use the concentration of zinc ions higher than $12 \mathrm{~g} / \mathrm{l}$ because it leads to obtain greater granularity than is desirable, and this applies to low concentrations of $6 \mathrm{gm} . / 1$ because it leads to drop in current efficiency.

High current density was not preferred in production of zinc powder since it gives a compacted deposit of zinc and combined with raised temperature of bath. The use of mechanical mixing is restricted due to it gives low productivity of desired particle size distribution. Also, the factors affecting the preparation of zinc powder by electrochemical process were correlated by empirical relationships and can be used in design calculations for the preparation and production process zinc powder

\section{REFERENCES}

1. Industry Segment Profile. "Metal Powder Production", EPRI Center for Materials Production, SIC 3399 Copyright (C) 2000.

2. Lux L., Galova M., and Orinakova R. "Chem. Papers" 52,(6),736-740 (1998)

3. Xiao-yi S., Yu-chun Z., Yan-hui Z. "Transaction Nonferrous Metals Society China" 20, 236-239 (2010)

4. Vilchis-Carbajal S., Gonzalez I., and Lapidus G.T. "Journal of Applied Electrochemistry" 30, 217-229, (2000). 
5. Rocha Poco J. G., Guardania R., Shimmi C. S., Giulietti M. " Materials Research, 9, 2, 131-135, (2006)

6. Obanr.L.” Romanian Reports in Physics", Volume 56, No. 3, 505 - 516,( 2004)

7. Abd M. M., "Preparation of nickel powder using an electrochemical process" Thesis, 2002, Military College of Engineering, Chemical Engineering Department

8. Calusaru A.," Electrodeposition of meta powder", 1979

9. Gomes A., Silva Pereira M.I.," Electrochimica Acta” 52,863-871, (2006)

10. International zinc association http://www.zinc.org

11. Sharifi B., Mojtahedi M. Goodarzi M., Vahdati Khaki J. "Hydrometallurgy" 99, $72-$ $76(2009)$

12. Ballesteros J.C., Diaz-Arista P., Meas Y., Ortega R., Trejo G. "Electrochimica Acta” 52,3686-3696 (2007)

13. Alejandro R., Sairi L., Jose L., Nava L., Rivera F. F. "Electrochimica Acta” 56, 14551459 (2011).

14. Zhu L., Zhang H. "Ultrasonics Sonochemistry” 15,393-401 (2008)

15. Zhu L., Zhang H., Weiping L., Liu H. "Journal of Physics and Chemistry of Solids" 70, 45-54 (2009)

16. Vazquez-Arenas J., Sosa-Rodriguez F., Lazaro I., Cruz R.” Electrochimica Acta”79, $109-116(2012)$

Table (1): Effect of electrolyte type on the nature of particle size distribution, productivity and current efficiency.

Cathode: stainls steel Anode: Zinc Current Density: 0.12 Ampere/ $\mathrm{cm}^{2}$ Operating time: 3 Hours

\begin{tabular}{|c|c|c|c|c|c|c|c|}
\hline \multirow[b]{2}{*}{$\begin{array}{c}\text { Electrolyte } \\
\text { type }\end{array}$} & \multirow{2}{*}{$\begin{array}{l}\text { Initial zinc } \\
\text { ions } \\
\text { concentrat } \\
\text { ion } \\
(\mathrm{g} / 1)\end{array}$} & \multirow{2}{*}{$\begin{array}{l}\text { Weight } \\
\text { Of } \\
\text { Zn } \\
\text { powder } \\
\text { g. }\end{array}$} & \multirow[b]{2}{*}{$\begin{array}{c}\text { Total } \\
\text { Productivity } \\
\mathrm{g} /\left(\mathrm{cm}^{2}\right. \\
\mathrm{hr} .)\end{array}$} & \multicolumn{2}{|c|}{$\begin{array}{c}\text { Particle size distribution } \\
\%\end{array}$} & \multirow[b]{2}{*}{$\begin{array}{l}\text { Productivity } \\
\text { From } \\
\text { less than } 106 \\
\text { micron } \\
\text { g. } /\left(\mathrm{cm}^{2} \mathrm{hr} \text {. }\right)\end{array}$} & \multirow[b]{2}{*}{$\begin{array}{c}\text { Current } \\
\text { Efficiency } \\
\%\end{array}$} \\
\hline & & & & $\begin{array}{l}\text { Large than } \\
106 \text { micron }\end{array}$ & $\begin{array}{l}\text { Less than } \\
106 \\
\text { micron }\end{array}$ & & \\
\hline $\begin{array}{c}\text { Alkaline } \\
200 \mathrm{~g} / 1 \\
\mathrm{NaOH}\end{array}$ & 12.04 & 44 & 0.111 & 39.5 & 60.5 & 0.0672 & 75.16 \\
\hline $\begin{array}{l}\text { Acidic } \\
\mathrm{H}_{2} \mathrm{SO}_{4} \\
\mathrm{pH}=6\end{array}$ & 12.10 & 13.84 & 0.035 & 28 & 72 & 0.0252 & 23.5 \\
\hline
\end{tabular}


Table (2): Effect of mixing type on the nature of particle size distribution, productivity and current efficiency

Cathode: stainls steel Anode: Zinc Current Density: 0.12 Ampere/ $\mathrm{cm}^{2}$ Operating time: 3 Hours

\begin{tabular}{|c|c|c|c|c|c|c|c|}
\hline \multirow[t]{2}{*}{$\begin{array}{l}\text { mixing } \\
\text { type }\end{array}$} & \multirow{2}{*}{$\begin{array}{l}\text { Initial zinc } \\
\text { ions } \\
\text { concentration } \\
(\mathrm{g} / \mathrm{l})\end{array}$} & \multirow{2}{*}{$\begin{array}{l}\text { Weight } \\
\text { Of } \\
\text { Zn } \\
\text { powder } \\
\text { g. }\end{array}$} & \multirow{2}{*}{$\begin{array}{l}\text { Total } \\
\text { Productivity } \\
\text { g. } /\left(\mathrm{cm}^{2} . \mathrm{hr} .\right)\end{array}$} & \multicolumn{2}{|c|}{$\begin{array}{c}\text { Particle size } \\
\text { distribution } \\
\%\end{array}$} & \multirow{2}{*}{$\begin{array}{l}\text { Productivity } \\
\text { From } \\
\text { less than } 106 \\
\text { micron } \\
\text { g. } /\left(\mathrm{cm}^{2} \text {.hr. }\right)\end{array}$} & \multirow{2}{*}{$\begin{array}{c}\text { Current } \\
\text { Efficiency } \\
\%\end{array}$} \\
\hline & & & & $\begin{array}{r}\text { Large } \\
\text { than } 106 \\
\text { micron }\end{array}$ & $\begin{array}{l}\text { Less } \\
\text { than } 106 \\
\text { micron }\end{array}$ & & \\
\hline $\begin{array}{c}\text { Natural } \\
\text { mixing } \\
\text { (by gas) }\end{array}$ & 6.05 & 58.0 & 0.146 & 7.75 & 92.25 & 0.1346 & 66.1 \\
\hline $\begin{array}{l}\text { Mechanical } \\
\text { Mixing } \\
(300 \mathrm{rpm})\end{array}$ & 6.2 & 74.0 & 0.186 & 70.88 & 29.22 & 0.054 & 84.3 \\
\hline
\end{tabular}

Table (3): the constants of empirical models (Current efficiency and Productivity).

\begin{tabular}{|c|c|c|}
\hline Constants & Current Efficiency $\left(Y_{1}\right) \%$ & Productivity $\left(\mathbf{Y}_{2}\right)$ \\
\hline $\mathrm{a}_{0}$ & -884.65 & +6225.1 \\
\hline $\mathrm{a}_{1}$ & -2.5 & +174.3 \\
\hline $\mathrm{a}_{2}$ & -1351.2 & +3442.8 \\
\hline $\mathrm{a}_{3}$ & +55.62 & -196.6 \\
\hline $\mathrm{a}_{4}$ & -0.04 & $0.001 \sim 0.0$ \\
\hline a5 & +12945.18 & -58189.7 \\
\hline$\overline{a_{6}}$ & -1715.78 & +12689.7 \\
\hline$\overline{\mathrm{a} 7}$ & +878.99 & -1704.0 \\
\hline as & -0.96 & -1224.7 \\
\hline a9 & -0.39 & -2.4 \\
\hline
\end{tabular}




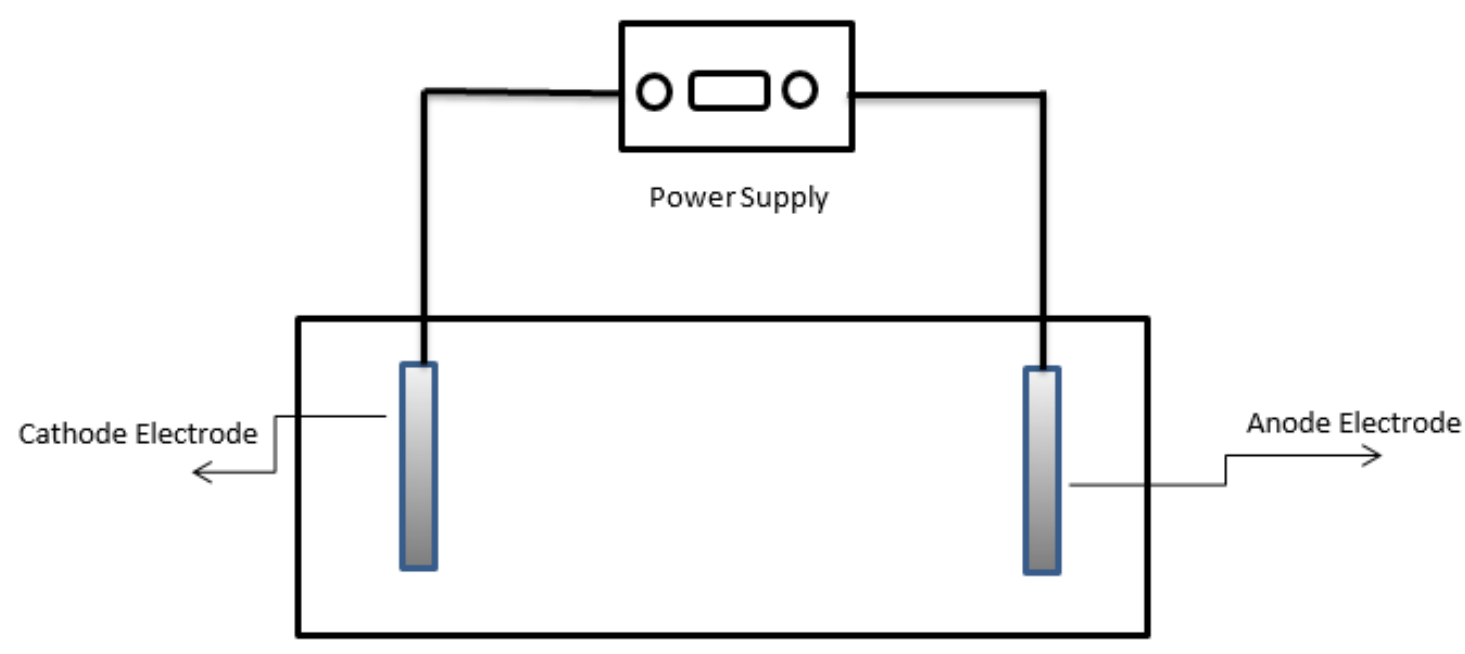

Cell Body

Fig. (1): a simple sketch of electrochemical cell for zinc powder preparation.

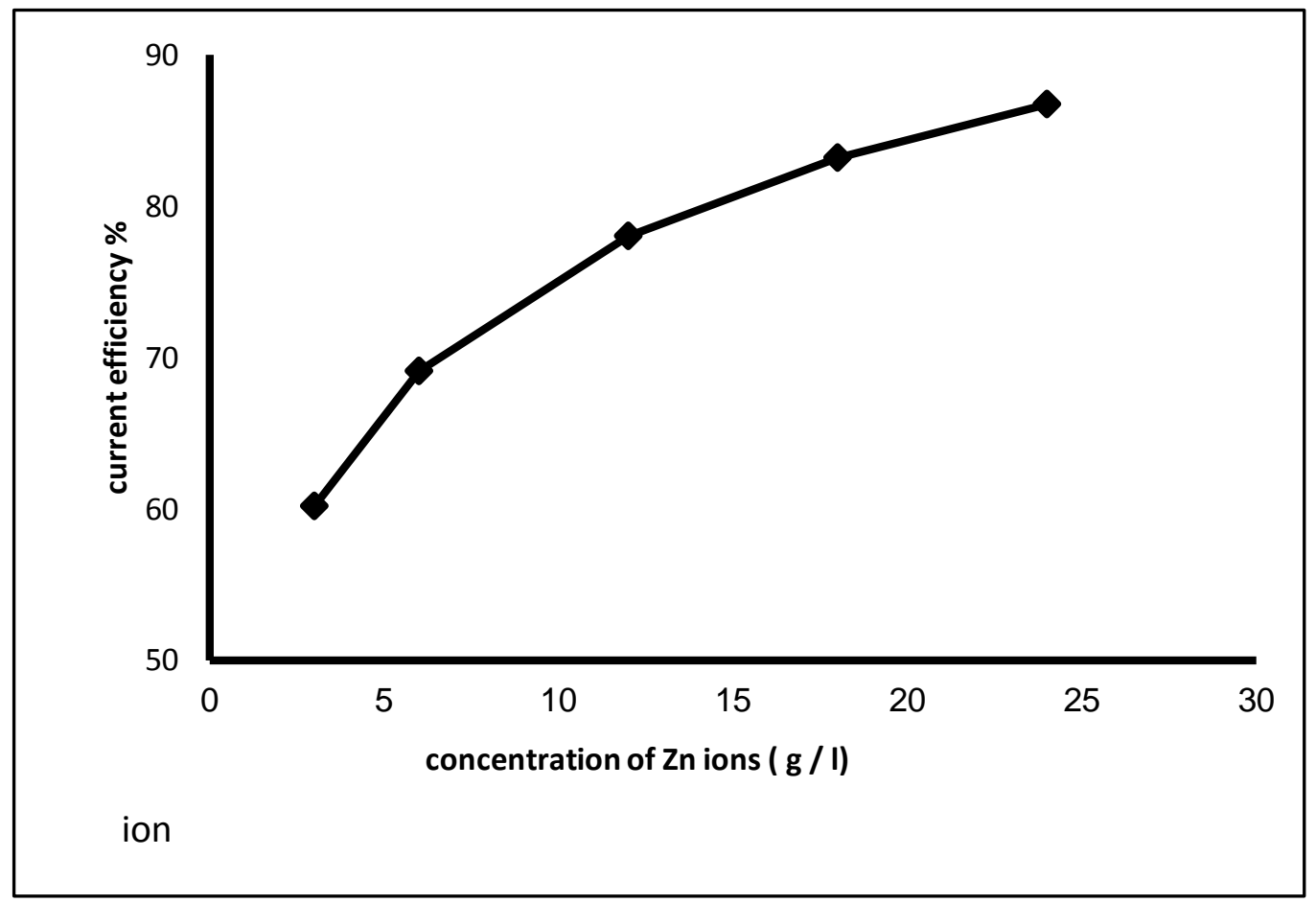

Fig. (2): The relation of current efficiency with concentration of zinc ion. 


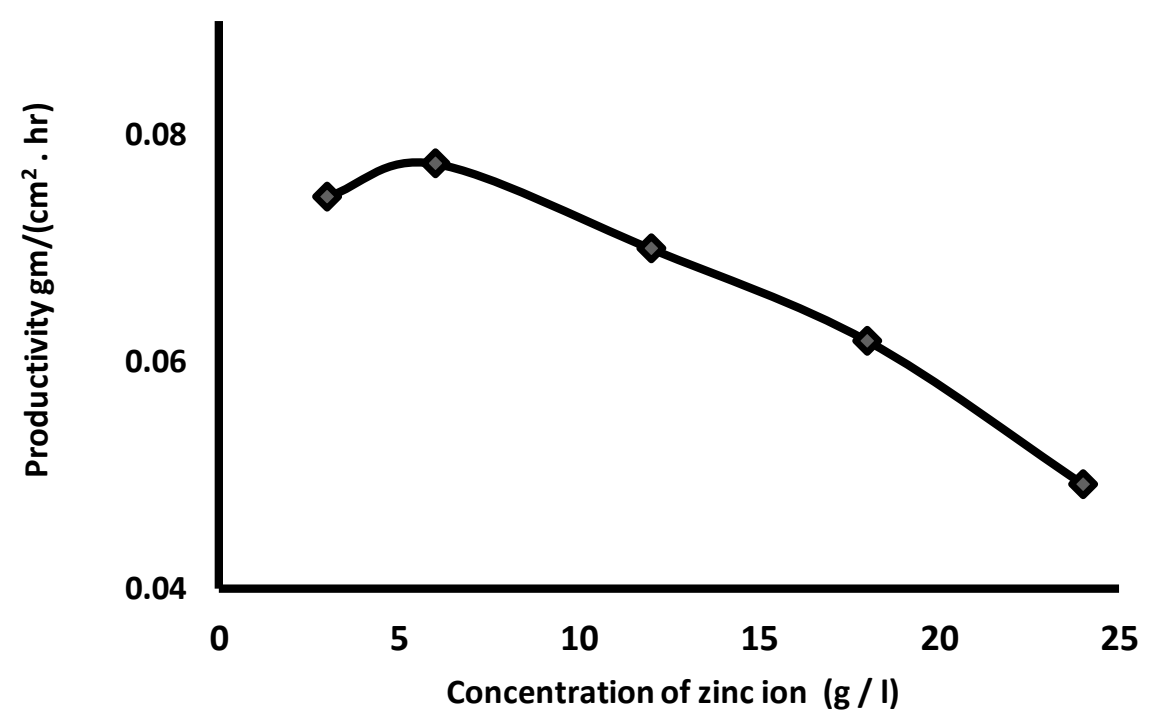

Fig. (3): The relation of Productivity with Concentration of zinc ion.

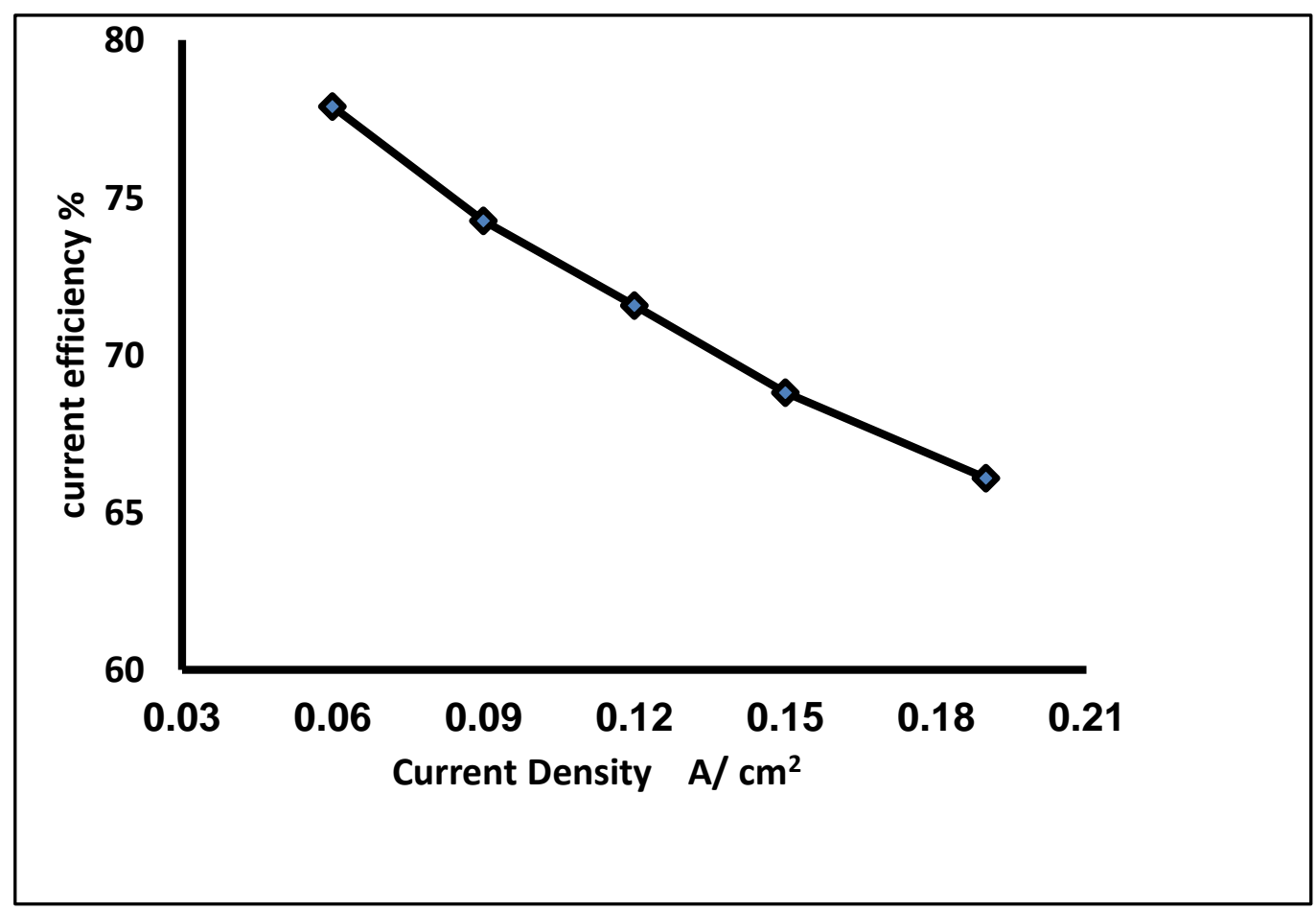

Fig (4): The relation of current efficiency with current density. 


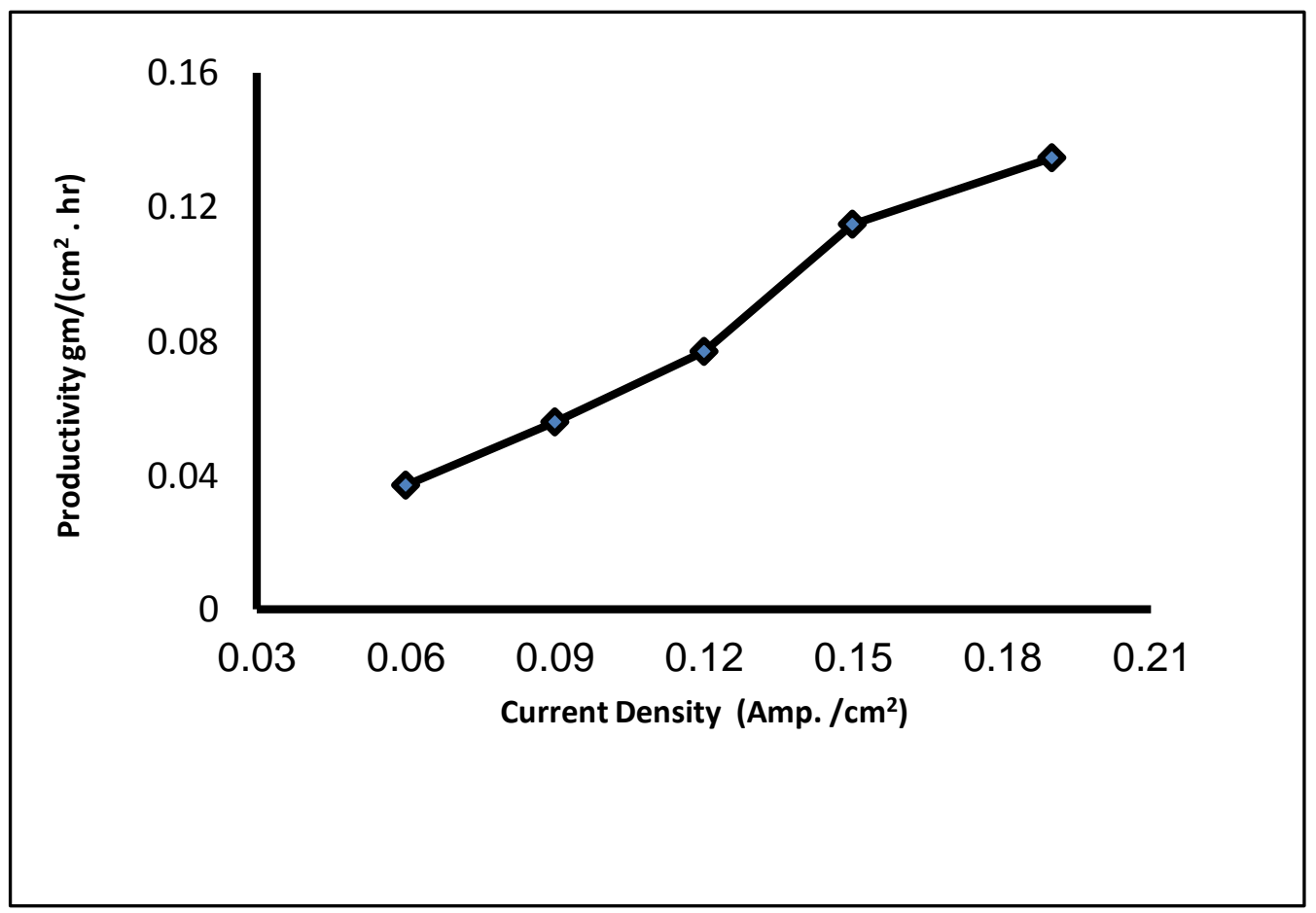

Fig. (5): The relation of Productivity with current density.

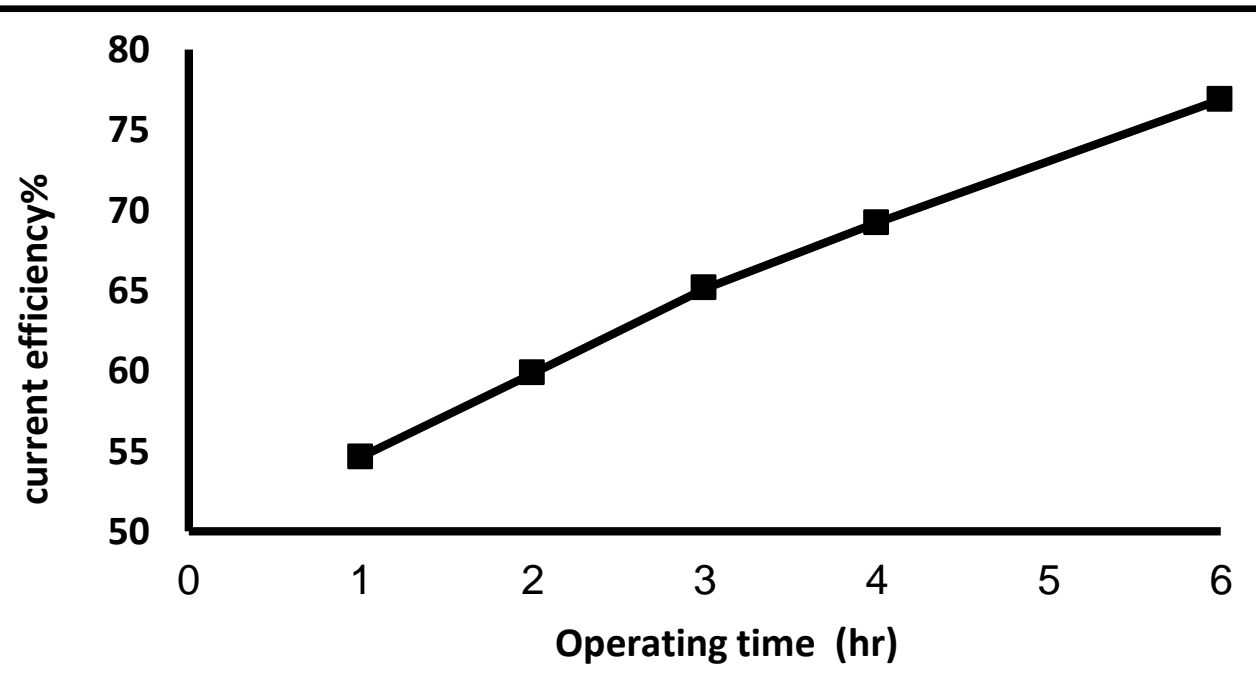

Fig. (6): The relation of current efficiency with operating time of electrolysis. 


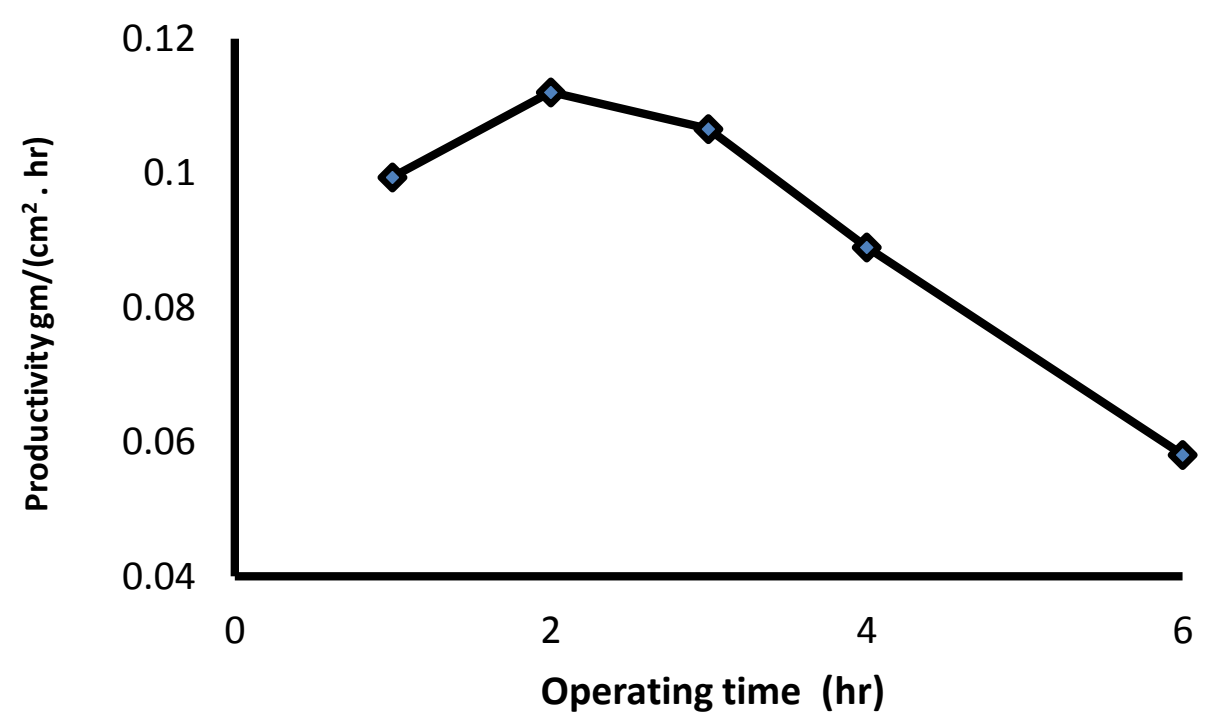

Fig. (7): The relation of productivity with operating time of electrolysis.

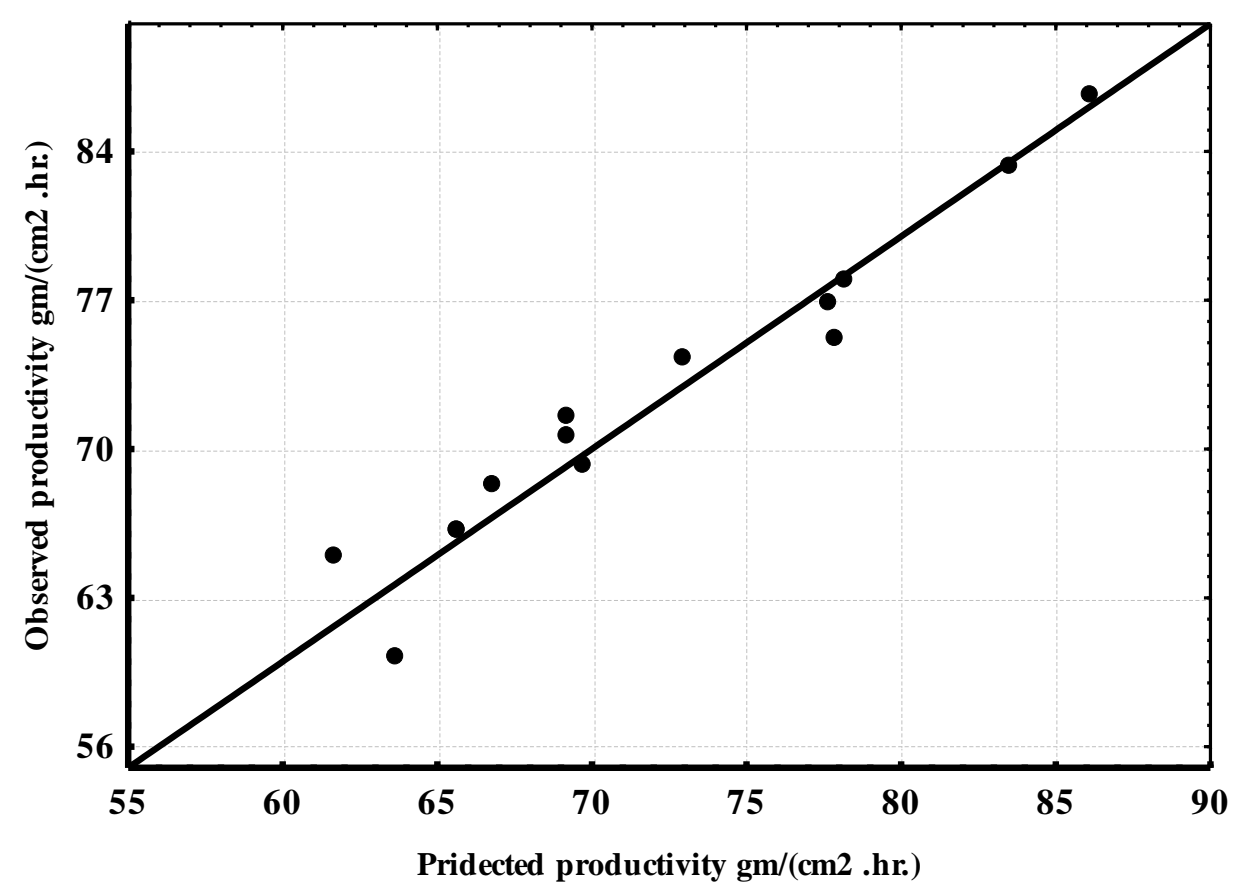

Fig. (8): the relation between the experimental and predicted results of productivity. 


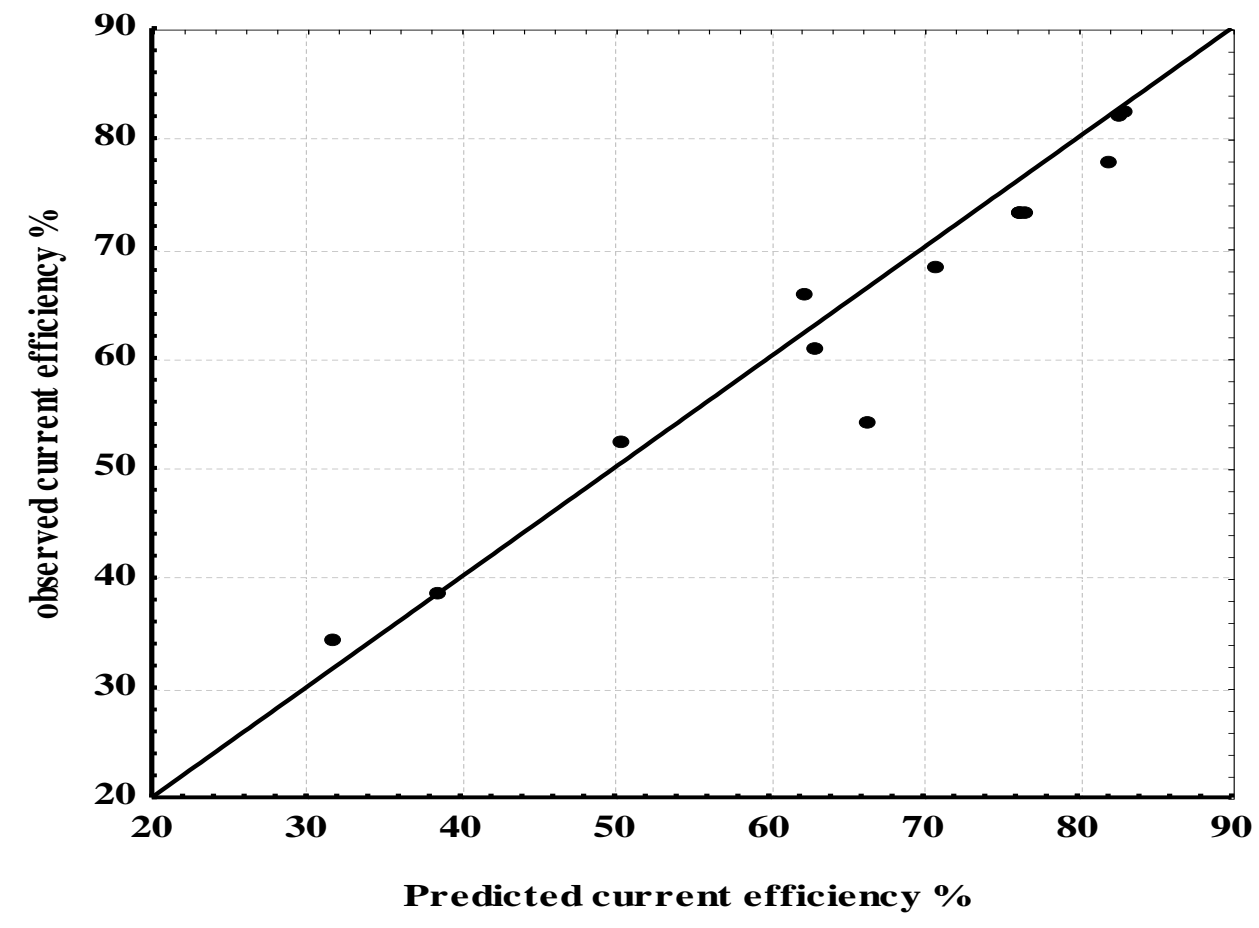

Fig. (9): the relation between the experimental and predicted results of current efficiency. 
دراسة تجربيية لتحضير مسحوق الخارصين بالطريقة الكهروكيميائية

$$
\text { كلية الهندسة / جامعة ديالى على الثمري }
$$

تناول هذا البحث دراسة و نثخيص العوامل والظروف التشغيلية المؤثرة على مواصفات مسحوق الخارصين

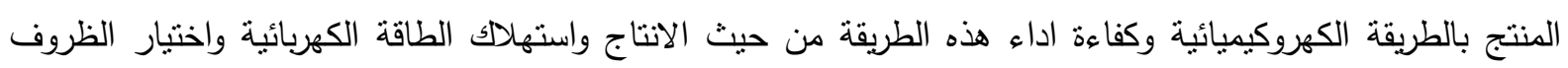

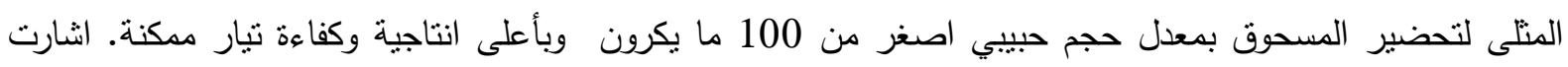

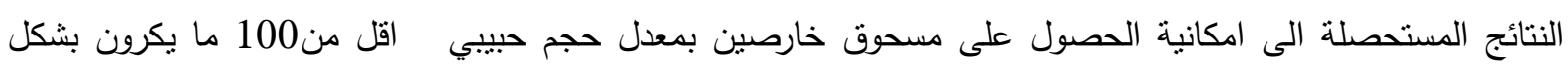

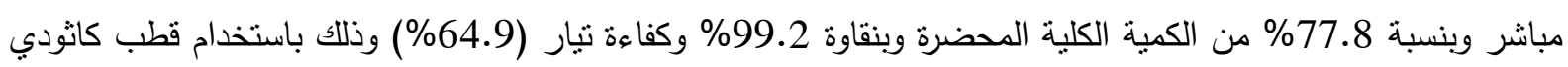

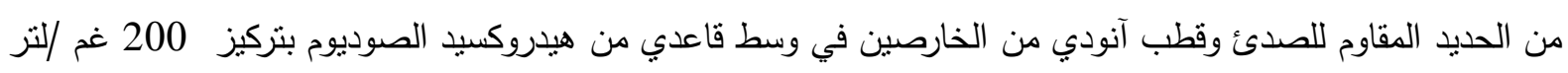

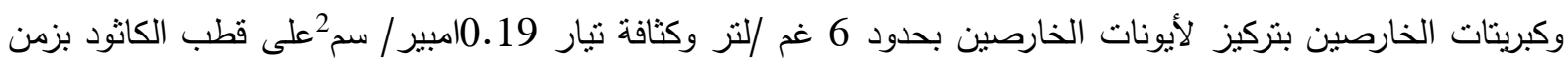

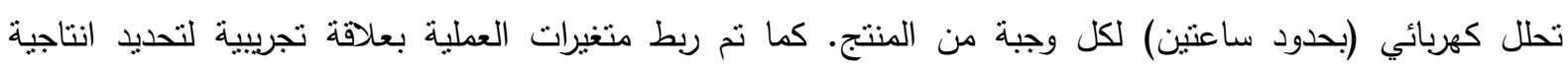

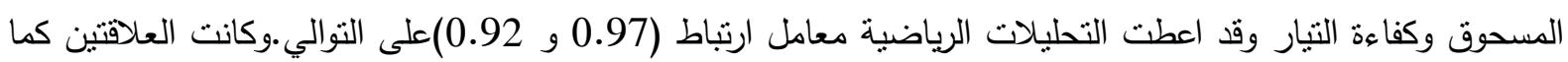
كفاءة التيار $(Y 1)=-884.65-2.5 X_{1}-1351.2 X_{1} X_{2}+55.62 X_{1} X_{3}-0.04 X_{1}^{2}+12945.18 X_{2}$ $-1715.78 X_{2} X_{3}+878.99 X_{2}^{2}-0.96 X_{3}-0.39 X_{3}^{2}$

$$
\begin{aligned}
\text { الانتاجية }\left(Y_{2}\right)= & 6225.1+174.3 X_{1}+3442.8 X_{1} X_{2}-196.6 X_{1} X_{3}-58189.7 X_{2} \\
& +12689.7 X_{2} X_{3}-1704.0 X_{2}{ }^{2}-1224.7 X_{3}-2.4 X_{3}{ }^{2}
\end{aligned}
$$

الكلمات الـالـة: مسحوق الخارصين، الترسيب الكهربائي، كفاءة التيار، انتاجية المسحوق. 